\title{
6. Engaging communities in environmental communication
}

Abstract: This article makes a case for alternative communication models as a means of strengthening networks both for dialogue and social action in environmental communication. It first charts the emergence of the environmental movement in the Pacific region as a consequence of 50 years of nuclear testing. This is followed by a discussion of contemporary environmental concerns facing Pacific communities and the networks of solidarity that have emerged. Participatory media provides an important platform for local communities through which they can share knowledge, create awareness and provide their own perspectives on environmental issues.

Keywords: collaboration, environmental communication, environmental movements, networks, Pacific, participation, participatory media, sharing

\section{USHA SUNDAR HARRIS}

Macquarie University, Sydney

\section{Introduction}

-HE STORY of modern environmental movements is one of people power. When people aspire for change they will take action to bring it about. As communities around the world have become aware of large-scale degradation of their waterways, forests, oceans and air they have turned to civic action and grassroots democracy to demand change. From the streets of New York to the Himalayan villages in northern India, from the forests of Tasmania to the coral lagoons of the Pacific Islands, citizens have banded together to protest against chemical poisoning, deforestation and nuclear testing in their 'backyard'.

Environmental movements result from deep ecological concern in ordinary people about threats to their natural habitat as a result of unsustainable development activity. At the heart of such protest movements is an agenda for social, economic and political change which seeks a better deal for both the natural and human environment through policy reforms and promulgation of social values that ensure sustainable use of natural resources. Concerns about preserving the ecological balance, inequitable distribution of resources, social 
justice, and emancipation of marginalised and displaced peoples have mobilised grassroots action for social change (see Maldonado, Colombi \& Pandya, 2013; Dalton, Recchia \& Rohrschneider, 2003; Jain, 1984). The deep discontent felt by individuals and communities in their everyday life progressively acquires broader 'networks of solidarity' as local direct action is supported by national and global acts of resistance (Dutta, 2012, p.34). For Castells (2009, p. 300) social movements are a result of 'social actors aiming for cultural change' which he explains as 'a change of values and beliefs processed in the human mind on a scale large enough to affect society as a whole'. Political change occurs when institutions adopt these new values in response to the cultural change. Effective communication and collaboration among actors are essential elements in achieving this transformation as Castells (2009, p. 301) elucidates:

Social movements are formed by communicating messages of rage and hope. The specific structure of communication of a given society largely shapes social movements. In other words, social movements, and politics, insurgent or not, spring up and live in the public space. Public space is the space of societal, meaningful interaction where ideas and values are formed, conveyed, supported, and resisted; space that ultimately becomes a training ground for action and reaction [italics in original text]. (Castells, 2009, p. 301)

Castell's use of the term 'public space' aligns with the Habermasian public sphere where the ferment of ideas and political action takes place. As Brulle explains: 'The public sphere is where social movement organisations can identify problems, develop possible solutions, and create sufficient political pressure to have them addressed by constitutional governments' (Habermas in Brulle, 2010, p. 4).

The ecological impact of human action has led to air and water pollution, deforestation, loss of biodiversity and danger from radioactive waste disposal, as well as the long term climate change impacts such as desertification, rising sea levels and frequent extreme weather events, to name just a few. Expanding on the range of the 1970s and 80s environmental movement, contemporary environmental protests seek to protect traditional sites, and conserve forests, rivers and land for future generations. Environmental activists have challenged multinational interests whose actions are motivated by profit or national governments striving for national economic growth. Examples of these include the Chipko movement in India, Franklin River Dam protests in Tasmania, the Dakota Access Pipeline protests by Standing Rock Sioux tribe in the United States, and a series of battles between mining giants and traditional communities in Papua New Guinea.

This article makes a case for alternative communication models as a means of strengthening environmental networks both for dialogue and political action. 
Participatory media provides an important platform for local communities through which they can share knowledge, create awareness and provide their own perspectives on environmental issues. It begins by charting the emergence of the environmental movement in the Pacific region as a consequence of 50 years of nuclear testing. This is followed by a discussion of contemporary environmental concerns facing Pacific communities, and the networks of solidarity that have given Pacific peoples a common voice against neo-colonial policies, resource exploitation by foreign powers, and a desire for political independence. The article first reviews key milestones in the global environmental movement beginning in the 1960 s to provide a background for the discussion.

\section{Background}

Between 1800 and the mid-1900s countries in the northern hemisphere underwent rapid industrialisation as fossil fuels in the form of oil and coal provided a cheap and abundant source of energy for powering the industrial complex. While economic growth and technological innovations had brought many benefits such as electrification, better yields in agricultural food production and greater affordability in car and home ownership, use of coal power was also the cause of many ills both to human health and the natural environment. People in industrialising countries suffered the side effects of carbon pollution as millions of tons of coal were burned to provide power to factories. The Great Smog of 1952 in the United Kingdom took place during an unusually cold period in December as a result of an anti-cyclone which trapped pollution from factory chimneys in the lower atmosphere. The UK Met Office describes its effects:

\section{A fog so thick and polluted it left thousands dead wreaked havoc on London in 1952. The smoke-like pollution was so toxic it was even reported to have choked cows to death in the fields. It was so thick it brought road, air and rail transport to a virtual standstill. (The Great Smog of 1952, 2015)}

Impurities in the atmosphere were measured in tonnes including dangerous levels of carbon dioxide, hydrochloric acid, fluorine compounds, and sulphur dioxide which had converted into sulphuric acid. More than 4,000 people died as a result of the Great Smog. Similar evidence of man-made environmental degradation emerged in other places in the northern hemisphere. In Sweden, there was concern about pollution in the form of sulphur emissions from the United Kingdom and Central Europe. The resulting acid rain and the acidity of Scandinavia's lakes and streams caused large-scale fish death. The health and productivity of forests' soils and trees were also damaged. In 1967, Sweden became the first nation in the world to take government action in developing environmental regulations when it created the Swedish Environmental Protection Agency (Johnson, 2012). 
In the United States great natural spaces were being 'tamed' by emptying lakes and filling in flowing creeks in order to build roads and great cities during the industrial revolution. Large-scale degradation of the natural environment had an impact on human health. Ten years after the Great Smog in Britain, American marine biologist and nature writer, Rachel Carson, warned against the hazards of chemical pesticides namely Dichlorodiphenyltrichloroethane (DDT). In her critically acclaimed book Silent Spring (1962), Carson questioned humans' domination of nature made possible by modern scientific discoveries: 'Only within the moment of time represented by the present century has one speciesman-acquired significant power to alter the nature of the world' (p. 5). Her book depicted a future world where spring no longer meant a joyous celebration of life because all life — birds, apple blossoms, fish and even children — had been 'silenced' by the insidious effects of DDT. Carson warned of ecological destruction of whole natural systems caused by humans' attempts to control pests, and through the industrial manufacture and indiscriminate use of DDT. Her singular attempts to expose the insidious role of man-made pesticides raised public awareness about the fragile nature of the environment and the intricate interconnectedness of the ecosystem.

Sweden proposed the idea of a United Nations conference on the Human Environment in 1968. In putting the case for the conference, Sweden's Ambassador to the UN, Sverker Astrom, urged world leaders to find solutions to environmental problems since it was in the interest of all peoples on earth, because 'Man depends for his survival on an infinitely complex system of relationship and balance between innumerable living organisms, all existing in or on the extremely thin crust of earth or just above it' (Johnson, 2012, p. 9).

The time was also right for an environmental movement which would catalyse the agency of American people. The first grassroots environmental action took place on the first Earth Day 22 April 1970 when 20 million Americans filled the city streets, parks, town squares and foreshores all across the United States to call for environmental protection. Students, housewives, labourers, farmers and office workers converged in public spaces demanding action from their government to become better guardians of the land, rivers, lakes, air and all living things that needed these natural resources to survive. Founder of Earth Day, Senator Gaylord Nelson (How the First Earth Day Came About, n.d.) recalled the immediate and immense response to his announcement for Earth Day:

Earth Day worked because of the spontaneous response at the grassroots level. We had neither the time nor resources to organise 20 million demonstrators and the thousands of schools and local communities that participated. That was the remarkable thing about Earth Day. It organised itself. 
Telegrams, letters and telephones were used to network and organise local action. Groups that had been fighting against oil spills, polluting factories and power plants, raw sewage, toxic dumps, pesticides, freeways, the loss of wilderness, the extinction of wildlife, and nuclear testing suddenly realized they shared common values (The History of Earth Day, 2017). The modern environmental movement was thus born thanks to the efforts of people all over the world who demanded greater environmental protection.

In the Global South the structural inequities in the global economic system controlled by imperial powers framed the debates around environmentalism aligned with democratic and human rights principles. Independence from colonial rule would emancipate developing nations and give them greater control over land and water resources. Examples include the Gandhian independence movement of 'Satyagraha', an action of non-violent non co-operation against the British rule in India, and Julius Nyerere's 'Ujamaa' policies which prioritised family and community in social and economic development.

\section{Environmental movement in the Pacific}

In the Pacific, like other developing regions, the environmental movement was framed within the larger emancipatory politics for self determination and indigenous rights to land and natural resources. Between 1946 and 1996, Oceania was the site for nuclear testing by the United States, Britain and France. A total of 315 atmospheric and underground tests were carried out in the colonial territories of the Marshall Islands, Gilbert and Ellis Islands (now Kiribati and Tuvalu) and Moruroa and Fangataufa atolls. Alister Barry's documentary A Nuclear Free Pacific (1988) makes the point: 'The view of the South Pacific is that of a region of peace. The reality is that the South Pacific has played the role of midwife to the nuclear arms race. The irony is that it was a role imposed on the region by its allies.' The colonial powers had little regard for the wellbeing of Pacific Island inhabitants who were under their jurisdiction. Instead, the Oceanic region, with 96 percent sea surface and thousands of uninhabited islands, was seen as a 'safe zone' because of its distance from the metropolitan centres of the world. Smith (1997, p. 1) explains that during the 'post-war period the micro-states of the Pacific have been generally dismissed as 'political backwaters'... and Pacific Islanders portrayed as passive actors - as opposed to recognising their abilities to influence events'.

Within the region there was rising concern about nuclear fallout and its health implications on Pacific Island communities and marine life which was their main food source. In 1975, the first conference of the Nuclear Free and Independent Pacific (NFIP) in Suva, Fiji brought together church leaders, academics, students, emerging political leaders, environmental activists and indigenous community groups (see Robie, 2014). As a young student in Papua New Guinea at the time, 
Rex Rumakiek was campaigning to raise awareness about the West Papua independence movement. He remembers:

It was an exciting time. People really felt connected to the issue. It was inspiring to go to the meeting. There were fights, there were cries because people felt like they were discovering something new, something that could solve the problems. They found their voice and their networks through this movement. (Interviewed by author, 4 November, 2016)

Rumakiek, who later became one of the leading campaigners for West Papua independence, recalls the meeting as a historically important event that marked the emergence of a collective Pacific consciousness.

The people realised that these issues are connected - the nuclear issue, the danger of nuclear and colonisation, these issues are connected. The fact that these devices are being tested on indigenous land is because people have no freedom to make decisions, they are still under a colony so they need to be liberated, they need their freedom so they can stop these devices to be tested on their ground. (Ibid.)

The meetings marked a watershed in Pacific political consciousness and gave rise to the environmental movement to end nuclear testing in the region. As political awareness grew within the region throughout the 70s and 80s, Pacific Islanders asserted their own political agenda, channelling their efforts through the Nuclear-Free and Independent Pacific (NFIP) movement. NFIP was a loose collective of civil society representatives who formulated the People's Charter for Nuclear Free and Independent Pacific in 1983. It states in its Preamble: 'We, the people of the Pacific will assert ourselves and wrest control over the destiny of our nations and our environment from foreign powers, including the TransNational Corporations' (NFIP, 1983).

The French government met the rising opposition to its activities in the Pacific with military style response when in 1985 it bombed the Greenpeace anti-nuclear flagship, the Rainbow Warrior, which was moored in Auckland Harbour, New Zealand (Robie, 2014). Despite international condemnation, French nuclear testing continued in the Pacific until 1996. France maintains its jurisdiction over French Polynesia known as 'Overseas Lands of France', as well as New Caledonia and Wallis and Futuna.

The region has experienced other environmental struggles between the local population and foreign interests. Bougainville and OK Tedi mines in Papua New Guinea endured ecological destruction as a direct result of bad mining practices (Kirsch, 2007). Australian mining giant BHP's operations at the OK Tedi copper-gold mine in the western province of Papua New Guinea resulted in 
one of the worst human-caused ecological disasters. Mine wastes were dumped in the OK Tedi and Fly Rivers, causing large scale damage to the surrounding forests and wildlife, poisoning the river system and village gardens and leading to the displacement of villagers from their traditional lands. A class action by Papua New Guinean landowners forced BHP to commission a report into its operations at OK Tedi mines. In 1996 the company reached an out-of-court settlement with the landowners for an estimated US \$500 million. With BHP's withdrawal from the mine its commitment to clean up the polluted areas remains to be met (Troubled Waters, 2012).

In Bougainville, conflict ensued between landowners and mine operators as a result of pollution from mine tailings to the surrounding environment and its impact on the islanders' traditional way of life. Panguna Mines, one of the world's biggest open cut copper mines, was owned and operated by a subsidiary of the mining giant Rio Tinto. While the mine generated billions of dollars of revenue for the PNG government and huge profits for the mine operators, Bougainville landowners received little compensation for their land and rivers which were being poisoned as reported in The Sydney Morning Herald: '...millions of tonnes of acid-laced mine tailings killed the Jaba and Kawerong rivers. The rivers had been a source of water and food for thousands, but large sections now resemble a moonscape, forcing people to leave their homes' (Flitton, 2016). With their demands unmet, a rebel group made up of young Bougainville landowners formed the Bougainville Revolutionary Army (BRA) and fought a bloody civil war which drove out both the PNG government forces and the mining giant. The decade long conflict which began in 1988 cost 20,000 lives and led to the closure of the mine (see Robie, 2014; Phillips, 2015). The Autonomous Bougainville Government continues to seek environmental justice from mining polluters to clean up large areas of the land which remain uninhabitable (Flitton, 2016).

In West Papua similar concerns are recorded in the operation of the Freeport copper mine where 200,000 tonnes of tailings per day (over 80 million tonnes per year) are dumped in the river systems causing floods, deforestation and grave impacts on community health and livelihoods (Troubled Waters, 2012). In the case of West Papua, which is under Indonesian rule, the mining operations not only imperil the environment, but also the indigenous population, who are considered to be at risk of becoming 'an anthropological museum exhibit of a bygone culture' (Schulman, 2016). Many small island nations rely exclusively on their river systems for fresh water. With prolonged and more severe droughts due to climate change, protection of rivers and streams from long-term pollution is more critical than ever before.

The Pacific Islanders also face numerous home grown ecological challenges. These include poor urban planning, waste disposal, urban drift which has led to overpopulation in cities and towns, energy inefficiency and overuse of natural resources. 
The Secretariat of the Pacific Regional Environment Programme (SPREP) has identified four main regional priorities in its 10-year strategic plan (SPREP 2017: 10): Climate Change Resilience

1. Ecosystem and Biodiversity Protection

2. Waste Management and Pollution Control

3. Environmental Governance

\section{Networks and Pacific regionalism}

Networks are important for building resilient communities. Three pillars -collaboration, sharing and active participation are needed for networks to function effectively. The idea of networks is found in nature as Harper (2012, p. 3) explains: 'The most fundamental concept for ecological understanding is the notion of a system as a network of interconnected and interdependent parts [...]. Thus an ecosystem means the "community" of things that live and interact in parts of the geophysical environment'. This idea aligns with White's (2003, p. 43) explanation of the participatory process whereby groups of people come together to 'pursue mutual interests and projects' in different forms of network. She states, 'The key to establishing networks is creating a context of ongoing dialogue, consensual thinking, and shared commitment to action...' In this article, network is defined as human-to-human relationships which may be assisted by other communication technologies such as audio, text and video messaging. These may include internet-based social networks such as Twitter, Facebook, YouTube, and mobile technologies, especially smart phones. With advances in technology human networks cover huge expanses to include not only our socio-cultural affiliations, but the global community in which communication enables the building of relationships and sharing of knowledge and information on a vast scale.

The idea of sharing is found in many cultures and also is a core principle in reciprocity. To engender a culture of sharing, people must be involved in meaningful exchanges of knowledge and skills which enable trust building. White explicates:

In the process of sharing, people can arrive at more clear understanding of their own life circumstances. By sharing, people can realize that they are not alone with their problems. Through sharing people can acquire useful knowledge and understanding. (White, 2003, p. 53).

The Pacific social structure is based on strong kinship networks and a culture of reciprocity. The act of giving and receiving is entrenched within the traditional value system of Pacific cultures. One form of this is commonly referred to as 'kerekere' or 'borrowing favour' and arises out of communal practice in 
Fiji. Reciprocity generates unity and continuity. As an important aspect of the Fijian social system, Ravuvu (1983, p. 250) presents the concept schematically in the following equation: Positive relationship $=$ reciprocation $=$ recognition, respect and appreciation $=$ strengthening of the bond $=$ incorporation and unity $=$ continuity.

In island studies the interconnectedness of islands is an important framework of analysis. Pacific scholars have argued that the Oceanic region can be imagined as 'a sea of islands' which have the Pacific Ocean as their common home (Hau'ofa, 1994:152). In the 21st century Pacific Island nations are strengthening their networks across a wide spectrum of socio-cultural, economic, political and scientific endeavours (see Harris, 2014). This solidarity is most pronounced in the area of climate change negotiations. In 2015, leaders of the Pacific Islands Development Forum signed the Suva Declaration on Climate Change which called for an agreement 'to stabilise global average temperature increase to well below $1.5^{\circ} \mathrm{C}$ above pre-industrial levels'. The Declaration reflects the concerns of all Pacific islands nations by noting that 'climate change poses irreversible loss and damage to our people, societies, livelihoods, and natural environments; creating existential threats to our very survival and other violations of human rights to entire Pacific Small Island Developing States'. The main positions put forward in the Suva Declaration are reflected in the final agreement of the 21 st session of the Conference of Parties (COP21) in Paris. The Suva declaration enabled Pacific Island nations to put a cohesive Pacific voice for the first time in climate change negotiations. The strong-arm tactics of its more powerful neighbour, Australia, which had tried to water down the Pacific leaders' statement on climate change, failed to work. The election of Ambassador Peter Thomson of Fiji as President of the United Nations General Assembly in 2016 and Fiji's appointment to hold the presidency of COP23 in Bonn, Germany next year are further proof of a strengthening Pacific diplomacy on the world stage.

Regional environmental networks have emerged to represent civil society actors. The Pacific Island Climate Action Network (PICAN) presents a united voice for civil society across the Pacific island countries advocating for climate justice at regional and at the international levels. As part of a three tiered network, PICAN is made up of smaller country-based networks - i.e VCAN in Vanuatu, KiriCAN in Kiribati and TCAN in Tuvalu - and is linked to the worldwide Climate Action Network (CAN) which has over 900 non-government organisations 'working to promote government and individual action to limit human-induced climate change to ecologically sustainable levels' (Pacific Island Climate Action Network, 2017). Pacific Climate Warriors from 350.org Pacific enlists youth to take global action on climate change. In 2014, Pacific Climate Warriors paddled out in traditional canoes to blockade the world's largest coal port in Newcastle in Australia. Through their banner 'we are not drowning, we are fighting', Pacific 
Climate Warriors are reframing the narrative to show that Pacific islanders are not passive victims but proactive civil society actors demanding climate justice. Smaller NGOs such as Wan Smolbag Theatre work at community level to raise awareness about a range of social and environmental issues. Through their travelling theatre groups and film productions, the NGO teaches about waste management, climate change, and the ecological importance of turtles and reefs in Vanuatu and other Pacific Islands.

\section{Participatory media in Environmental Communication}

Communication has been the cornerstone of human relationship and the glue that binds networks. Flor (2004) reminds us that:

Environmental communication is founded in our culture, specifically, in traditional cultures. We see this in the environmental wisdom handed down from one generation to another; in the meanings that we attach to seasons; and in the reverence that our traditional cultures attach to farming and other forms of natural resource exploitation. Nature and culture are seen not as dichotomies but as a continuum. (Flor, 2004, p. 18)

Communication about the environment is also influenced by the doctrines espoused by powerful groups who seek to exploit the earth's resources. Mainstream media plays a crucial role in shaping our understanding of Nature and about critical environmental issues, such as anthropogenic climate change, through its agenda-setting role and framing of environmental issues (see Boykoff \& Boykoff, 2007; Cox, 2013; Lakoff, 2010). The metanarrative is shaped by the political and economic imperatives of private capital and national development priorities which dominate mainstream news coverage in opposition to the voices of people who demand environmental protection and stewardship. The subaltern voices that disrupt the dominant structures have struggled to summon sustainable communicative processes and media forms that enable uncorrupted representation of their views. New media and Web 2.0 have changed this imbalance in information flow, and the growing influence of technology must factor in the social and economic forces that have shaped these technologies. If human evolution is dependent upon collective learning using networks which share information and knowledge (Christian, 2011) then centralisation of communication structures that benefit some and keep out others would seem counter-productive.

Flor $(2004$, p. 4) states that environmental communication 'is the deliberate exchange of environmental information, knowledge, and even wisdom'. Both vertical and horizontal communication networks are needed to share messages of solidarity and resistance. Vertical communication assists in disseminating information about environmental concerns and organising strategic action. 
Horizontal communication engenders dialogue whereby participants listen to each other, share opinions, and debate issues with an aim to finding solutions. The phenomenological approach to communication gives significant attention to issues of interaction, social relations with a focus on networks and 'interaction developed in social networks' (Galindo Cáceres, 2006, p. 536).

Participatory media is used here to emphasise the pivotal role of participation of lay-people in making media content which is of special value to them and their community. The value resides in the inherent purpose for which the content was created. The process of production invites collaboration, dialogue and mutual problem solving whereby people gain critical understanding of the problem and the action they need to take to solve it (Kheerajit \& Flor, 2013). Thus collaboration, sharing and participation are essential characteristics by which community members generate knowledge and build resilient communities. Participatory media forms can include songs, dance, visual arts, craft, folk theatre, and audio/visual digital tools such as video, radio and social media. Here the boundary between producer and consumer of content disappears. Participatory media is not about accessing technology, but ways in which it enables people to have a voice. The groups who are excluded from participating in top down hierarchical communication systems, be it in village meetings or in mainstream media, and are only passive receivers of information, become active agents of change when they participate in the process of content creation to find solutions to problems which impact on their everyday lives. As such, participatory media can be defined as subaltern media culture which enables ordinary people to collaborate in identifying problems, collectively gathering information, analysing, designing and sharing media content which has value to them and their network. Through this process of production marginalised people gain control of their own storytelling and by implication their own lives.

Environmental researchers recognise the value of local engagement using participatory approaches in community based adaptation (See Janif et.al.,2016; Haynes \& Tanner, 2015; Mataki, Koshy \& Nair, 2008). Participatory media provides an important platform for communities to share knowledge and create awareness about environmental issues by providing their own perspectives. A study of participatory media for disaster and climate change risk reduction with women and children in Nepal found that their viewpoints shed a new understanding on recurrent problems. Plush (2009) observes:

As climate scientists and decision-makers reach to the micro-level to deepen their knowledge on community impacts, participatory video with marginalized groups has the potential to not only provide data, but offer prioritized solutions in the voice of those most impacted. (Plush, 2009, p. 26) 
Plush's study points out that women and children presented alternative solutions to community based adaptation programs which differed from outside interventions driven by experts. The participatory video production process enabled 'women and children to investigate, understand and amplify their climate concerns in their own voice in a way that leads to action' (Plush, 2009, p. 10). In a similar study conducted in the Philippines designed to increase young people's knowledge of disaster and climate change issues, Haynes and Tanner (2015, p. 367 ) note that the films made by youth identified not only the impacts but the 'underlying social causes of disaster'. They contend that participants must have free reign over their own story telling and not be guided by underlying motives of the funding agency which may want to achieve a particular outcome.

Participatory workshops conducted by this author also reveal that community members want access to media platforms which enable them to record and share content instantly. The author conducted two workshops using smart phones with community artists at Further Arts and Oxfam fieldworkers in Vanuatu. While both groups had access to smart phones with audio visual recording capability, neither group had proactively used these features for environmental communication. Once they understood the theory and practice of participatory media, participants realised how it could be integrated in their work practice, for example capturing interviews about community concerns while on field visits or creating better workflow by producing reports in audio visual form. The author, who had used participatory video in the past, found that knowledge of mobile phones as a multi-media tool generated greater excitement among participants as it was more immediate than the process of shooting and editing using video cameras. While adept at using smart phones, participants said learning to use an editing app (in this case Filmora Go, a free android video editor) had filled an important knowledge gap which made it possible for them to instantly record, edit and share content. Notwithstanding the aesthetics of producing content which could be considered amateur, there remains the question of what is more important to the viewer - relevance of the information being shared or the quality of content, or both. The editing app was a midway solution providing a more polished content with titles, voice over and music that would have greater appeal in the wider community.

In environmental communication the focus has either been on mainstream media reporting of environment issues or top down strategic communication to change attitude and behaviour in the population. Participatory media projects enable those who are at the coalface of climate change impacts to enter the conversation normally led by elite perspectives. 


\section{Conclusion}

Environmental movements seek to protect Earth's ecological system from human activity which produces long term detrimental impact on land, water, air and the well being of all living things. Participatory media enables communities to share knowledge and create awareness about a range of issues from their own experience. It has the ability to change the conversation from alarmist notions of climate change to a more practical discussion of impacts that are both real and immediate such as access to energy, food and water security, sanitation, jobs and livelihoods (Faris, Lipscombe, Whitehead, \& Wilson, 2014). During times of crisis participatory media platforms such as Facebook and Twitter become a critical source of information when mainstream media cannot gain access to a disaster zone or has no interest in the crisis. The communication between participants empowers endogenous networks and uncovers unique solutions arising from the particular context of the community. In doing so it embeds local knowledge and finds solutions from within.

\section{References}

Boykoff, M. T., \& Boykoff, J. M. (2007). Climate change and journalistic norms: A case-study of US mass-media coverage. Geoforum, 38(6), 1190-1204.

Brulle, R. J. (2010). From environmental campaigns to advancing the public dialog: Environmental communication for civic engagement. Environmental Communication, 4(1), 82-98. doi:10.1080/17524030903522397

Carson, R. (1962). Silent spring. Boston: Houghton Mifflin

Castells, M. (2009). Communication Power. Oxford: Oxford University Press.

Christian, D. (2011). Maps of time: An introduction to big history (2nd ed.).

Berkeley, CA: University of California Press.

Cox, R. (2013). Environmental communication and the public sphere (3rd ed.) Los Angeles, CA: Sage.

Dalton, R. J., Recchia, S., \& Rohrschneider, R. (2003). The environmental movement and the modes of political action. Comparative Political Studies, 36(7), 743-771. doi: $10.1177 / 0010414003255108$.

Dutta, M. J. (2012). Voices of resistance: Communication and social change. West Lafayette, IN: Purdue University Press e-Books.

Faris, S., Lipscombe, S., Whitehead, S. \& Wilson, D. (2014). From the ground upChanging the conversation about climate change, Policy briefing \#11. BBC Media Action. Retrieved from www.bbc.co.uk/mediaaction/publications-and-resources/ policy/briefings/policy-climate-change

Flitton, D. (2016, August 21). Rio Tinto's billion-dollar mess: 'unprincipled, shameful and evil'. The Sydney Morning Herald. Retrieved March 17, 2017, from www.smh. com.au/world/billiondollar-mess-a-major-disaster-the-people-do-not-deserve-tohave-20160817-gquzli.html

Flor, A. G. (2004). Environmental communication: Principles, approaches and strategies of communication applied to environmental management. Quezon City, Philippines: University of Philippines Open University.

Galindo Cáceres, L. J. (2006). 'Historical notes on possible communicology: A hypothetical 
configuration and trajectory'. In Gumucio-Dagron, A. \& Tufte, T. (Eds.), Communication for social change anthology: Historical and contemporary readings, 536-544 New Jersey, NJ: Communication for Social Change Consortium (CFSC).

Harper, C. (2012). Environment and society: Human perspectives on environmental issues. Boston, MS: Prentice Hall.

Harris, U. (2014). Communicating climate change in the Pacific using a bottom-up approach, Pacific Journalism Review, 20(2), 77-95. doi:10.24135/pjr.v20i2.167

Harris, U. and Papoutsaki, E. (2008). Unpacking 'Islandness'. In E. Papoutsaki, \& U.S. Harris (Eds.). South Pacific Islands Communication: Regional Perspectives, Local Issues. 1-12. Singapore: Asian Media Information and Communication Centre.

Hau'ofa, E. (1994). Our sea of islands. The Contemporary Pacific, 6(1), 147-161

Haynes, K., \& Tanner, T. M. (2015). Empowering young people and strengthening resilience: Youth-centred participatory video as a tool for climate change adaptation and disaster risk reduction. Children's Geographies, 13(3), 357-371. doi:10.1080/1 4733285.2013.848599.

Jain, S. (1984). Women and people's ecological movement: A case study of women's role in the Chipko movement in Uttar Pradesh. Economic and Political Weekly, 19(41), 1788-1794.

Janif, S. Z., Nunn, P. D., Geraghty, P., Aalbersberg, W., Thomas, F. R. \& Camailakeba, M. (2016). Value of traditional oral narratives in building climate-change resilience: Insights from rural communities in Fiji. Ecology and Society, 21(2), 7. Doi:10.5751/ ES-08100-210207.

Johnson, S. (2012). UNEP_- The first 40 years: New York NY: United Nations Environment Programme.

Kheerajit, C., \& Flor, A. G. (2013). Participatory development communication for natural resources management in Ratchaburi province, Thailand. Procedia-Social and Behavioral Sciences, 103, 703-709. doi:10.1016/j.sbspro.2013.10.390

Kirsch, S. (2014). Mining capitalism: The relationship between corporations and their critics. Berkeley, CA: University of California Press.

Kirsch, S. (2007). Indigenous movements and the risks of counterglobalization: Tracking the campaign against Papua New Guinea's Ok Tedi mine. American Ethnologist, 34(2), 303-321. doi:10.1525/ae.2007.34.2.303

Lakoff, G. (2010). Why it matters how we frame the environment, Environmental Communication: A Journal of Nature and Culture, 4(1), 70-81, doi: 10.1080/17524030903529749

Maldonado, J. K., Colombi, B., \& Pandya, R. (Eds.). (2013). Climate change and indigenous peoples in the United States: Impacts, experiences and actions. New York, NY: Springer.

Mataki, M., Koshy, K., \& Nair, V. (2008). Top-down, bottom-up: Mainstreaming adaptation in Pacific island townships. In J. A. Neil Leary, V. Barros, I. Burton, \& J. Kulkarni (Eds.), Climate change and adaptation. pp. 265-278. London, UK: Earthscan.

Milstein, T. (2009). Environmental communication theories. In Littlejohn, S. and Foss, K. (Eds.), Encyclopedia of Communication Theory, 345-350. Thousand Oaks: Sage Publications. doi: 10.4135/9781412959384.n130

Nelson, G. (n.d.). How the first earth day came about. Retrieved on January 19, 2016, from http://earthday.envirolink.org/history.html

Phillips, K. (2015). Bougainville at a crossroads: independence and the mine. Retrieved March 16, 2017, from www.abc.net.au/radionational/programs/rearvision/bougainville-at-a-crossroads/6514544 
Plush, T. (2009). Video and voice: How participatory video can support marginalized groups in their efforts to adapt to a changing climate. Synthesis paper for Masters in Participation, Power and Social Change. Institute of Development Studies.

Ravuvu, A. (1983). The Fijian way of life. Suva: Institute of Pacific Studies, University of the South Pacific.

Robie, D. (2014). Don't spoil my beautiful face: Media, mayhem and human rights in the Pacific. Auckland, New Zealand: Little Island Press.

Smith, R. H. (1997). The nuclear free and independent Pacific movement after Muroroa. London, UK: Tauris Academic Studies.

Schulman, S. (2016). The $\$ 100 \mathrm{bn}$ gold mine and the West Papuans who say they are counting the cost. The Guardian. Retrieved March 17, 2017, from www.theguardian. com/global-development/2016/nov/02/100-bn-dollar-gold-mine-west-papuans-saythey-are-counting-the-cost-indonesia

White, S. A. (Ed.) (2003). Participatory video images that transform and empower, New Delhi, India: Sage Publications.

\section{Online resources}

Pacific Island Climate Action Network. (2017). Retrieved March 17, 2017 from https:// pacificclimateactionnetwork.wordpress.com/

The Secretariat of the Pacific Regional Environment Programme Strategic Plan 2017-2026. (2017). Retrieved March 15, 2017, from www.sprep.org/attachments/ Publications/Corporate_Documents/strategic-plan-2017-2026.pdf

The Great Smog of 1952. (2015). Retrieved on March 17, 2017, from www.metoffice. gov.uk/learning/learn-about-the-weather/weather-phenomena/case-studies/great-smog

The History of Earth Day. (2017). Retrieved January 17, 2016, from www.earthday.org/ about/the-history-of-earth-day/

Troubled waters: How mine waste dumping is poisoning our oceans, rivers, and lake. (2012). Retrieved March 17, 2017 from www.earthworksaction.org/files/publications/ Troubled-Waters_FINAL.pdf

Dr Usha Harris is a former television producer and journalist and teaches in the International Communication discipline at Macquarie University, New South Wales, Australia. Her use of communication technology for social inclusion has strongly informed her academic practice. As a researcher and practitioner of participatory media, she has trained Pacific Island communities in Fiji, Vanuatu, Kiribati, and New Zealand in the use of participatory media and mobile technologies to raise awareness about environmental issues including climate change impacts and adaptation. Dr Harris has a forthcoming book on the theme entitled, Participatory Media in Environmental Communication (Routledge).

usha.harris@mq.edu.au 